\title{
Determinants of market participation among smallholder farmers in Southwest Ethiopia: double-hurdle model approach
}

\author{
Kusse Haile ${ }^{1^{*}}(\mathbb{0})$, Engida Gebre ${ }^{2}$ and Agegnehu Workye ${ }^{2}$ (i)
}

\begin{abstract}
Background: Agricultural production by smallholder farm households is a means of livelihood for many rural households in developing economies, including Africa. Commercializing smallholder farmers in the agricultural sector is an indispensable path to boost economic growth and development of most developing countries, like Ethiopia. But, maize marketing has not been given due attention, which has potential production volume and marketability. Therefore, this study is designed to identify determinants of market participation decision and volume of supply among smallholder maize producer farmers in Southwest Ethiopia.
\end{abstract}

Methods: Data for this study were collected through cross-sectional survey from maize producer farm households. The primary data were generated by household survey using a pre-tested structured questionnaire. A both purposive and random sampling technique was used to draw an appropriate sample of 546 maize producer households for this cross-sectional survey study. The data were analyzed using descriptive statistics and double-hurdle econometric model.

Results: The result of the survey indicates that out of total 546 maize producers, 381 households are maize market participants and 165 households are non-participants. First hurdle model results show that nine variables_education level, farming experience, quantity of maize produced, cooperative membership, distance to nearest market, amount of credit received, off/non-farming income, number of oxen and perception about lagged price-significantly affect the market participation decision among maize producer farmers. The second hurdle result confirmed that seven variables — sex, family size, land allocated for maize, number of oxen, distance to nearest market, livestock holding and perception about lagged price—significantly affect the level of market participation by maize producer farmers.

Conclusion: The findings of this study revealed that understanding the factors and its extent is very important for policy-making to address the problem of market participation decision and level of participation among smallholder farm households. Therefore, the study suggests that important resource and socio-economic factors must take into consideration to enhance the productivity and strength supportive institutions or infrastructural facilities in the study area to improve market participation decision and level of participation of smallholders.

Keywords: Market participation, Level of participation, Double-hurdle, Maize, Southwest

*Correspondence: kussehaile@mtu.edu.et; kussehaile@gmail.com ${ }^{1}$ Department of Agricultural Economics, Mizan-Tepi University, P.O Box: 260, Mizan Aman, Ethiopia

Full list of author information is available at the end of the article

\section{Background}

Economy of Ethiopia is predominantly agrarian, where $95 \%$ of the farm land is cultivated by smallholder farmers and $90 \%$ of the total agricultural output comes out of them [1]. The contribution of smallholder farmers is high to the overall agricultural growth in the country 
and the overall economy of Ethiopia depends on agricultural sector development. The movement of agriculture sector depends entirely on what is happening in smallholder sub-sector [2]. Studies indicated that, smallholder farmers are a key solution for economic growth, and for alleviation of poverty and food security problems in developing countries. Considering that issue, Ethiopian government has targeted smallholder farmers as the focal point for economic transformation and agricultural development, and for meeting the current growing food demand [3-5]. Commercial transformation of subsistence agriculture is an indispensable pathway towards economic growth and development for many agriculturedependent famers in developing countries [6].

In Ethiopia, cereals are the major food crops both in terms of the area they are planted and volume of production obtained. Out of the total grain crop area, 79.83\% $(11,610,331$ hectares) was under cereals and it contributed $87.08 \%$ (about 283,922,484 quintals) of the grain production [7]. Maize is one of the most commonly available cereals and source of high-calorie staple human foods, feed for animals and other industrial raw materials in different parts of the country. Also, maize crop is the lowest cost source of cereal calories and effective maize production sector development could push Ethiopia's food supply to quickly reduce the national food deficit and keep pace with a rapid population growth [8]. Southwest Ethiopia, particularly Kaffa, Sheka and Bench Sheko zones, have good potential for cereal crops production for which smallholder farming have diversified from staple food subsistence production into more market-oriented and higher value commodities. In southern Ethiopia, out of the total land allocated for cereal crops, maize accounts 322,714.36 hectares with production level of 10,857,255.50 quintal [9]. But, majority of Ethiopia's smallholder farmers grow maize mostly for subsistence-oriented production, and about three-fourths of the output is consumed at the household level [8]. Rural households' participation in agricultural markets is vital important strategy for poverty alleviation and food security in developing countries [10].

Currently, the government of Ethiopia has designed and implementing second growth and transformation plan (GTP II) as strategy to bring a dynamic change by focusing on productivity improvement and commercial transformation of smallholder subsistence agriculture. Despite these efforts made to commercialize and transform subsistence crop production to production of high-value crops, the current reality shows that commercialization of smallholder farming is much below the expectations and farmers are not yet out of the subsistence-oriented agriculture, low productivity, low income, and low degree of specialization [1, 11-17]. Thus, it is not possible for the smallholder farmers to integrate with the market and enjoy the benefits of commercialization unless the already existing hurdles are removed and better environment is created. Specific study areas commercialization is affected by institutional factors, infrastructural and market-related factors, resource factors, and householdspecific characteristics that influence production and marketing [18-20].

Although, even if the government of Ethiopia focused on commercialization of subsistence agriculture as priority policy decision, market participation by smallholder farmers in Ethiopia is limited and agricultural markets are fragmented and not well integrated into wider market systems which increases transaction costs and reduces farmers' incentive to produce for the market [6]. Thus, there is a dearth of information on the commercialization process and marketing behavior of small holders in Ethiopia.

Despite their undisputed importance, most of the studies conducted on the determinants of smallholders' market participation have methodological gaps of only capturing the revealed marketing decisions of households while they ignored the volume of supply $[12,13$, 21-28]. In addition, their findings vary within and across countries due to heterogeneity of factors faced by smallholder farmers, maize market participation decision and factors hindering volume of supply in southwestern Ethiopia were not studied. There have been very limited studies regarding identifying status and determinants of market participation and implications of the challenges on decision-making of smallholder maize production. In this regard, the current study attempted to contribute to redressing this gap of knowledge for the market participation and its intensity in the study area. Therefore, the objective of the study was to identify the determinants of market participation and volume of supply by smallholder maize producers to figure out location-based analysis in Kaffa, Sheka and Bench Sheko Zones, Southwest Ethiopia.

\section{Materials and methods \\ Description of the study area}

The study was conducted in Kaffa, Sheka and Bench Sheko Zone of Southern Nations Nationalities and People's Regional State. Kaffa Zone lies within $07^{\circ} 00^{\prime}-$ $7^{\circ} 25^{\prime}$ North latitude and $35^{\circ} 55^{\prime}-36^{\circ} 37^{\prime}$ East longitude (Fig. 1). The altitude of the study sites ranges from 1600 to 1900 meter above sea level. The topography is characterized by slopping and rugged areas with very little plain land [29]. According to Central Statistical Agency report on population projection the total population of the zone in the year 2017 was estimated to reach 1,102,278. Out of the total population $49.14 \%$ and $50.86 \%$ are male and 


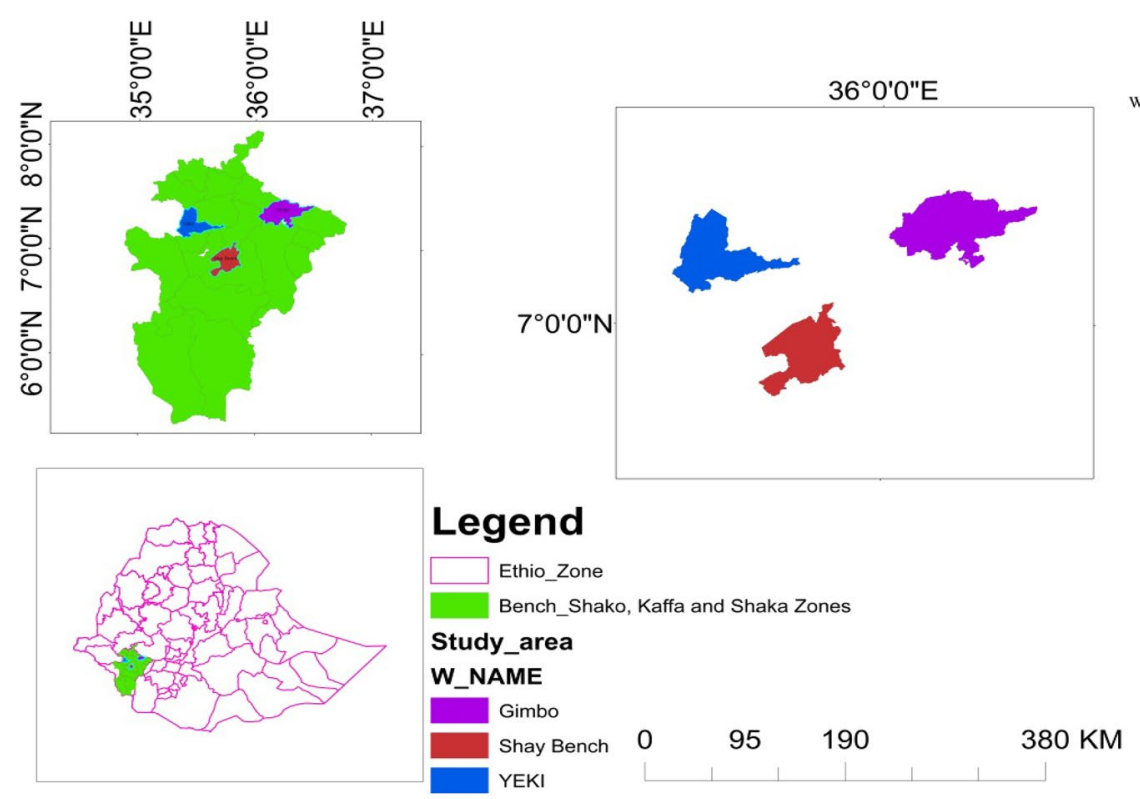

Fig. 1 Geographical location of the study area (Source: own design using ARCGIS, 2019)

female, respectively [30]. Bench Sheko Zone is located $561 \mathrm{~km}$ southwest of the capital city, Addis Ababa. The altitude of the zone varies between 700 and 2500 m.a.s.l., and the mean annual rainfall and temperature varies between $400-2000 \mathrm{~mm}$ and $15-27^{\circ} \mathrm{C}$, respectively. The total population of Bench Sheko zone in the year 2017 was estimated to reach 847,168 . Out of the total population $49.31 \%$ and $50.69 \%$ are male and female, respectively [30]. Also, Sheka zone lies between $7^{\circ} 24^{\prime \prime}$ to $7^{\circ} 52^{\prime \prime}$ $\mathrm{N}, 35^{\circ} 13^{\prime \prime}$ to $35^{\circ} 35^{\prime \prime} \mathrm{E}$ and 900 to 2700 m.a.s.l. The area coverage of Sheka zone is $2175.25 \mathrm{~km}^{2}$. It receives high amounts of rainfall, with an average between 1800 to $2200 \mathrm{~mm}$ per annum. The major crops grown in the zone are maize, sorghum, millet, beans, coffee, ginger, turmeric, "enset", wheat, barley and pea [31]. According to the report of Central Statistical Agency on these three zones, 852,433 quintal of maize produced from area allocated, 41,804 hectare with productivity of $20 \mathrm{qt} / \mathrm{ha}$ [32].

\section{Types and sources of data}

In order to generate the relevant data for this study, data were collected by a two-phase primary survey. First, preliminary survey was conducted to broadly understand the farming systems and the major types of crops grown in the study area. During this exploratory survey, formal and informal discussions were held with different stakeholders including crop producing farmers, DAs, agricultural marketing offices, non-governmental organizations (NGOs), and agricultural experts/officers. Purpose of this survey is to facilitate characterization of the existing farming systems and livelihood strategies of the farm households in the context of their specific socio-economic and biophysical, settings and to refine the study objectives, sampling methods and the survey instrument. Once having the basic information using need assessment survey, main survey was carried out using structured survey instrument. A scheduled interview was made using questionnaire with farm households. The questionnaire was pre-tested and amended based on the feedback received during pre-test. The enumerators, who can speak the local languages and are familiar with the culture of the local people were selected and trained on data collection procedures and interview techniques to simplify the complexity of data collection. Thus, primary data analysis results were supported by secondary sources like; reports of offices, journal articles, books, and empirical findings of different relevant published and unpublished materials to generate relevant supportive data.

\section{Sampling procedure and sample size determination}

Smallholder maize producers are the target population for this study. To draw representative sample, a combination of both purposive and random sampling techniques was used. The data were collected from purposively selected three zones, Kaffa, Sheka and Bench Sheko. These three zones were among major maize growing zones in southwestern Ethiopia. From these three zones, according to information obtained from the zones agricultural office, Gimbo district (from Kaffa zone), Shay 
Table 1 Zone, districts, Kebeles, and sample size proportion. Source: own sampling design

\begin{tabular}{|c|c|c|c|c|c|}
\hline Zone & District & Kebele & Target population & $\begin{array}{l}\text { Sample size } \\
\text { proportion }\end{array}$ & Percentage \\
\hline \multirow[t]{7}{*}{ Kaffa } & Gimbo & Kute & 1240 & 37 & 6.78 \\
\hline & & Yabkecha Keda & 637 & 19 & 3.48 \\
\hline & & Yabkecha Welega & 1039 & 31 & 5.68 \\
\hline & & Yertech & 1441 & 43 & 7.88 \\
\hline & & Kicho & 670 & 20 & 3.66 \\
\hline & & Gawo & 1608 & 48 & 8.79 \\
\hline & & Choba & 704 & 21 & 3.85 \\
\hline \multirow[t]{5}{*}{ Bench Sheko } & Shay Bench & Cheda & 1407 & 42 & 7.69 \\
\hline & & Maze & 1508 & 45 & 8.24 \\
\hline & & Kulagecha & 1273 & 38 & 6.96 \\
\hline & & Kuka & 1575 & 47 & 8.61 \\
\hline & & Shapagud & 804 & 24 & 4.40 \\
\hline \multirow[t]{3}{*}{ Sheka } & Yeki & Hibretfre & 1876 & 56 & 10.26 \\
\hline & & Adisbrhan & 1374 & 41 & 7.51 \\
\hline & & Shoshaa & 1139 & 34 & 6.23 \\
\hline Total & & 15 & 18,295 & 546 & 100.00 \\
\hline
\end{tabular}

Bench district (from Bench Sheko zone) and Yeki district (from Sheka zone) have a relatively higher potential in maize production than other districts in these zones. Thus, these districts were selected purposively. First, Kebeles $^{1}$ in the three districts was stratified into maize producers and non-producers. Then, among the maize producing Kebeles, 15 Kebeles $(7$ Kebeles from Gimbo district, 5 Kebeles from Shay Bench district and 3 Kebeles form Yeki district) were randomly taken in order to obtain representative sample household heads from the strata. Finally, from total list of maize producer farm households in the 15 Kebeles, 546 maize producer sample households were selected by using simple random sampling (SRS) technique based on probability proportional to size (PPS) as presented in Table 1.

\section{Method of data analysis}

A both descriptive and econometric statistical tool was used to analyze the data. Under descriptive analysis, mean, frequency, percentages, and standard deviations were used. Inferential statistical tests such as $T$-test and Chi-square test were used for the existence of any statistically verifiable differences among farmers participated and their counterfactuals. Under econometric analysis, double-hurdle model was used to estimate market participation decision and level of participation by smallholder maize producers.

${ }^{1}$ Kebele is the lowest administrative unit.

\section{Specification of the econometric model}

Different limited dependent models such as doublehurdle model, Heckman two-stage models, and restrictive Tobit model have been used to study crop market participation and its intensity of participation. But, the model specification mainly depends on the purpose of the study and the type of data available. One of the most used methods for modeling market participation behavior is the censored regression model, also called the Tobit model. Tobit model assumes that a household not participating in marketing is making a rational decision and this leads to inconsistent parameter estimates [33].

Double-hurdle is the model introduced as a more flexible and alternative to Tobit model [34]. It assumes a twostep decision process: the first step involves the decision whether to participate in market or not and secondly the intensity of participation. The model estimation involves a Probit regression to identify factors affecting the decision to participate in marketing by using all sample households in the first-stage, and in the second-stage, the intensity of the participation was analyzed by truncated regression model.

Heckman two-stage model has been used extensively to correct for bias arising from sample selection [35]. In this model, the decision to participate is sequential two-stage decision-making process. One problem with the two-stage decision-making process is that the twostage decision-making processes are not separable due to unmeasured variables determining both the discrete and continuous decision, thereby leading to the correlation between the errors of the equations. If the two errors are 
correlated, the estimated parameter values on the variables determining the intensity are biased [36]. Besides, there were many zeros in the dependent variable of second-stage, OLS estimation was biased because of duplications of many zeros which results no variability.

The double-hurdle procedure with Probit and truncation regressions was used separately to correct the above limitations. The model is a parametric generalization of the Tobit and Heckman model, in which two separate stochastic processes determine the decision to participate and the level of participation [33]. In addition, using doublehurdle model provides consistent and asymptotically efficient estimates for all the parameters. Thus, double-hurdle model was used to analyze decision to participate and intensity of participation. Selection model was not appropriate for this data set since the mills lambda $(I M R=0.118)$ is insignificant. Thus, the Heckman is not appropriate for the data set of this study. Also, the most restrictive Tobit model and double-hurdle model were compared, and finally double-hurdle model found appropriate for the data set using model specification test (Tobittest $(\mathrm{LR})=2$ * (LL Probit + LL truncreg-LL Tobit)).

\section{Specification of double-hurdle model}

As specified below, the double-hurdle model involves two-step estimation procedure. In the first-stage, Probit regression was used to identify factors affecting adoption decision. The model takes a value 1 and 0 that are assigned to represent the choice whether a producer decides to adopt or not. The standard Probit model that assesses the household adoption decision was described in Eq. (1) as:

$$
\begin{aligned}
& D_{i}=\alpha Z_{i}, k+\varepsilon_{i} \\
& D_{i}=1, \text { if } D_{i}^{*}>0, \\
& D_{i}=0, \text { if } D_{i}^{*} \leq 0,
\end{aligned}
$$

where $D_{i}$ is a dummy variable that takes the value 1 if the producer participate in crop commercialization and 0 otherwise, $Z_{i}$ is a vector of independent variables hypothesized to influence participation decision, $k$ is the regressors, $\alpha$ is a vector of parameter to be estimated and $\varepsilon_{i}$ error term. In the second-stage, truncated regression that excludes part of sampled observation based on the value of the dependent variable was used [36]. The regression considers the observations that take 1 for participation decision. Therefore, the second hurdle represents the actual level of participation, expressed by the volume of supply; the truncated regression model with the lower left truncation equal to 0 was used to determine factors affecting the intensity of participation.
The truncated regression model for intensity of participation was described in Eq. (2) as:

$$
\begin{aligned}
& y_{i}=\beta_{i} \chi_{i}+\mu \lambda_{i}+\varepsilon_{i} \\
& y_{i}^{*}=\beta_{i} \chi_{i}+v_{i} \\
& y_{i}=\left\{y_{i}^{*} \text { if } y_{i}^{*}>0 \text { and } D_{i}=1 ; 0 \text { otherwise }\right\}
\end{aligned}
$$

where $y_{i}^{*}$ and $\mathrm{y}_{i}$ are latent and the observed intensity of participation, respectively, $x_{i}$ is a vector of variables influencing intensity of participation and $\beta$ is a vector of parameters to be estimated. The error terms are assumed to be independently and normally distributed as both decisions made by the individual producer independently which are as: $u_{i} \sim N(0,1)$ and $v_{i} \sim N\left(0, \sigma^{2}\right)$.

The log-likelihood function for the double-hurdle model that nests Probit model and a truncated regression model is given following [37] as:

$$
\begin{aligned}
\log L= & \sum \ln \left[1-\Phi\left(Z_{i}^{\prime} \alpha\right)\left(\frac{x_{i}^{\prime} \beta}{\sigma}\right)\right] \\
& +\sum_{+} \ln \left[\Phi\left(z_{i}^{\prime} \alpha\right) \frac{1}{\sigma} \phi\left(\frac{y_{i}-x_{i}^{\prime} \beta}{\sigma}\right)\right]
\end{aligned}
$$

where $\Phi$ and $\phi$ refer to the standard normal probability and density functions, respectively, $Z_{i}$ and $X_{i}$ represent independent variables for the Probit model and the Truncated model, respectively, $\alpha, \sigma$, and $\beta$ are parameters to be estimated for each model.

\section{Hypothesis, variable descriptions and expected sign}

Identifying factors determining market participation decision and level of participation of maize producers, exploring which factors significantly influence and how these factors are related with the dependent variables are required. Hence, the following dependent and independent variables were defined and hypothesized for this study as presented in Table 2 .

\section{Results and discussion Descriptive statistics}

The demographic, institutional, and resource ownership characteristics of sample households were addressed by different descriptive statistical measures such as frequency or mean and percentage values of variables used in the model briefly. As indicated in Tables 3 and 4, group comparisons of the market participants and non-participants were computed using $t$-test for continuous variables and $\mathrm{Chi}^{2}$-test for dummy variables. The result of the survey indicates that out of total 546 maize producer farm households, 381 households were participated in maize market and 165 households are non-participants in 2018/19 production year. 
Table 2 Summary of variable description and expected sign. Source: own design

\begin{tabular}{|c|c|c|c|c|}
\hline Variables & Type & Descriptions and measures & $\begin{array}{l}\text { Expected } \\
\text { sign } \\
\text { (hypothesis) }\end{array}$ & $\begin{array}{l}\text { Theoretical suggestions and } \\
\text { empirical literatures to support } \\
\text { hypothesis }\end{array}$ \\
\hline \multicolumn{5}{|l|}{ Dependent variable } \\
\hline Market participation decision & Dummy & $\begin{array}{l}\text { It is a binary dependent variable that } \\
\text { represents the probability of market } \\
\text { participation of the producers in the } \\
\text { maize market. The variable takes the } \\
\text { value of } 1 \text { for the household who } \\
\text { participate in the market, where as it } \\
\text { takes the value of } 0 \text { for the household } \\
\text { who does not participate in the maize } \\
\text { market }\end{array}$ & & \\
\hline Quantity of maize sold (Log) & Continuous & $\begin{array}{l}\text { A continuous variable that indicating } \\
\text { the amount of maize actually sold and } \\
\text { measured in kilogram }\end{array}$ & & \\
\hline \multicolumn{5}{|l|}{ Independent variables } \\
\hline Farming experience & Continuous & $\begin{array}{l}\text { A continuous variable measured in } \\
\text { years of farming }\end{array}$ & + & $\begin{array}{l}\text { This is supported by empirical study } \\
\text { conducted by }[38,39]\end{array}$ \\
\hline Sex of household head & Dummy & $\begin{array}{l}1 \text { if the household head is male and } 0 \\
\text { otherwise }\end{array}$ & \pm & $\begin{array}{l}\text { Empirical studies conducted by }[5,22 \text {, } \\
25,28,40,41] \text { found indeterminate } \\
\text { results }\end{array}$ \\
\hline Education level of $\mathrm{HH}$ & Continuous & $\begin{array}{l}\text { Education level of household heads in } \\
\text { number of years completed }\end{array}$ & \pm & $\begin{array}{l}\text { Empirical studies conducted by [ } 22, \\
42-44] \text { found indeterminate results }\end{array}$ \\
\hline Family size & Continuous & $\begin{array}{l}\text { Total number family size in the } \\
\text { household }\end{array}$ & + & $\begin{array}{l}\text { A study conducted by [ } 45-48 \text { ] found } \\
\text { positive result }\end{array}$ \\
\hline Number of oxen owned & Continuous & $\begin{array}{l}\text { Total number of oxen owned by the } \\
\text { household head interms of number }\end{array}$ & \pm & $\begin{array}{l}\text { This is supported by empirical study by } \\
{[49,49-51] \text { found indeterminate results }}\end{array}$ \\
\hline Land allotted for maize & Continuous & $\begin{array}{l}\text { Total land size allotted for maize crop } \\
\text { measured in hectare }\end{array}$ & + & $\begin{array}{l}\text { Empirical studies conducted by }[28,51 \text {, } \\
52] \text { positive result }\end{array}$ \\
\hline Participation in training & Continuous & $\begin{array}{l}\text { It takes } 1 \text {, if the household head } \\
\text { participated training and } 0 \text { other- } \\
\text { wise during survey period }\end{array}$ & + & Findings of [53] found positive effect \\
\hline Livestock holding & Continuous & $\begin{array}{l}\text { Total livestock holding in terms of } \\
\text { Tropical Livestock Unit (TLU), exclud- } \\
\text { ing oxen }\end{array}$ & \pm & $\begin{array}{l}\text { This is supported by findings of }[54,55] \\
\text { found indeterminate results }\end{array}$ \\
\hline Amount of credit & Continuous & $\begin{array}{l}\text { Amount of credit received by house- } \\
\text { hold in terms of Ethiopian Birr during } \\
\text { survey period }\end{array}$ & + & $\begin{array}{l}\text { This is supported by empirical study } \\
\text { conducted by }[14,56,57]\end{array}$ \\
\hline Quantity of maize produced & Continuous & $\begin{array}{l}\text { Total quantity of maize produced by } \\
\text { household in kilogram }\end{array}$ & + & $\begin{array}{l}\text { It is supported by empirical study con- } \\
\text { ducted by }[21,58] \text { found positive effect }\end{array}$ \\
\hline Cooperative membership & Dummy & $\begin{array}{l}1 \text { if household is member and } 0 \\
\text { otherwise }\end{array}$ & \pm & $\begin{array}{l}\text { Empirical studies conducted by }[59,60] \\
\text { found indeterminate results }\end{array}$ \\
\hline Distance to nearest market & Continuous & $\begin{array}{l}\text { Distance to nearest market in walking } \\
\text { minutes }\end{array}$ & - & $\begin{array}{l}\text { Empirical findings of [14] found nega- } \\
\text { tive effect }\end{array}$ \\
\hline $\begin{array}{l}\text { Perception about lagged market } \\
\text { price }\end{array}$ & Dummy & $\begin{array}{l}1 \text { if the household head has high } \\
\text { perception about market price and } 0 \\
\text { otherwise }\end{array}$ & + & $\begin{array}{l}\text { A study conducted by [44] found posi- } \\
\text { tive result }\end{array}$ \\
\hline Non/off-farm income & Continuous & $\begin{array}{l}\text { Amount of income obtained from } \\
\text { non/off-farm activities (in Ethiopian } \\
\text { Birr) annually }\end{array}$ & \pm & $\begin{array}{l}\text { Empirical studies conducted by }[39,42 \text {, } \\
61,62] \text { found indeterminate results }\end{array}$ \\
\hline Distance to nearest road & Continuous & $\begin{array}{l}\text { Distance to nearest all round road in } \\
\text { terms of walking minutes }\end{array}$ & - & $\begin{array}{l}\text { Empirical studies conducted by }[19,63] \\
\text { found negative effect }\end{array}$ \\
\hline
\end{tabular}

The survey result indicated that, the average age of maize market participants was about 41.730 years while for non-participants was about 43.455 years as presented in Table 3. This shows that, aged household heads were less participated in maize market than younger households. The average family size of the maize market participants was 5.719 and 5.812 for non-participants. This implies that large family could absorb a significant portion of the produce to home consumption. Study result shows that, the average education level of maize 
Table 3 Demographic characteristics of sample households. Source: Survey data, 2018/2019

\begin{tabular}{lcccc}
\hline Variable description & $\begin{array}{l}\text { Participant }(\boldsymbol{n}=\mathbf{3 8 1}) \\
\text { Mean (std. dev.) }\end{array}$ & $\begin{array}{l}\text { Non-participant }(\boldsymbol{n}=\mathbf{1 6 5}) \\
\text { Mean (std. dev.) }\end{array}$ & $\begin{array}{l}\text { Total }(\boldsymbol{n}=\mathbf{5 4 6}) \\
\text { Mean (std. dev.) }\end{array}$ & $\boldsymbol{t}$-value/ $\boldsymbol{\lambda}^{\mathbf{2} \text { value }}$ \\
\hline Age of household head & $41.730(10.897)$ & $43.455(11.925)$ & $42.251(11.234)$ & 1.650 \\
Family size & $5.719(2.284)$ & $5.812(2.866)$ & $5.747(2.472)$ & 0.403 \\
Education level of HH & $3.302(2.722)$ & $4.212(2.355)$ & $3.577(2.648)$ & $3.732^{* * *}$ \\
Farming Experience & $19.472(10.136)$ & $21.660(9.728)$ & $20.134(10.056)$ & $2.345^{* *}$ \\
Sex of HH: male & $302(68.330)$ & $140(31.670)$ & $442(80.950)$ & $2.328^{*}$ \\
Female & $79(75.960)$ & $25(24.040)$ & $104(19.050)$ & \\
\hline
\end{tabular}

"**", "**" and "***" represent statistical significance of factors at 10, 5 and $1 \%$ levels, respectively

Table 4 Resource ownership and institutional characteristics of sample households. Source: Survey result of 2018/2019

\begin{tabular}{|c|c|c|c|c|}
\hline Variable description & $\begin{array}{l}\text { Participant }(n=381) \\
\text { Mean (std. dev.) }\end{array}$ & $\begin{array}{l}\text { Non-participant }(n=165) \\
\text { Mean (std. dev.) }\end{array}$ & $\begin{array}{l}\text { Total }(n=546) \\
\text { Mean (std. dev.) }\end{array}$ & $t$-value $/ \lambda^{2}$ value \\
\hline Land allotted for maize (hectare) & $0.970(0.626)$ & $0.849(0.571)$ & $0.933(0.612)$ & $2.117^{* *}$ \\
\hline Quantity of maize produced (kilogram) & $1512.800(1408.420)$ & $673.333(486.320)$ & $1259.115(1266.152)$ & $7.463^{* * *}$ \\
\hline Quantity of maize sold (kilogram) & $963.614(1162.838)$ & $0.000(0.000)$ & $672.412(1067.230)$ & $10.639^{* * *}$ \\
\hline Number of oxen owned (count) & $2.388(1.338)$ & $2.103(1.328)$ & $2.302(1.340)$ & $2.294^{* *}$ \\
\hline Extension contact (frequency) & $7.567(9.208)$ & $11.782(11.479)$ & $8.841(10.125)$ & $4.547^{* * *}$ \\
\hline Amount of credit (Ethiopian Birr) & $4466.182(17,222.540)$ & $2252.150(4206.060)$ & $2921.230(10,130.520)$ & $2.355^{* *}$ \\
\hline Off/non-farm income (Ethiopian Birr) & $1292.650(3139.996)$ & $1201.697(2318.710)$ & $1265.165(2914.480)$ & 0.335 \\
\hline Distance nearest road (walking minutes) & $31.430(23.268)$ & $36.218(30.836)$ & $32.877(25.855)$ & 1.993 \\
\hline Livestock holding (TLU) & $5.141(2.452)$ & $4.952(2.507)$ & $5.084(2.468)$ & 0.823 \\
\hline Distance to nearest market (walking minutes) & $63.472(36.651)$ & $74.495(48.230)$ & $66.803(40.771)$ & $2.921^{* *}$ \\
\hline Lagged market price perception: good & $236(76.380)$ & $73(23.620)$ & $309(56.590)$ & $14.684 * * *$ \\
\hline Otherwise & $145(61.180)$ & $92(38.820)$ & $237(43.410)$ & \\
\hline Cooperative membership: members & $180(68.700)$ & $82(31.300)$ & $262(47.990)$ & 0.2775 \\
\hline Non-members & $201(70.770)$ & $83(29.230)$ & $284(52.010)$ & \\
\hline Participation in training: trained & $249(67.120)$ & $122(32.880)$ & $371(67.950)$ & $3.8965^{* *}$ \\
\hline Non-trained & $132(75.430)$ & $43(24.570)$ & $175(32.050)$ & \\
\hline
\end{tabular}

"**", "***" and "***" represent statistical significance of factors at 10,5 and $1 \%$ levels, respectively

market participants was 3.302 while that for non-market participants was about 4.212. Thus, the level of education was statistically significant at $1 \%$, signifying that the mean education level of market participants was less than that of non-market participants. As presented in Table 3, farming experience for maize market participants was 19.472 years while that for non-market participants was about 21.660 years. Also, 302 maize market participants and 140 non-participants were male-headed households. On the other hand, 79 participants, and 25 non-participants were female-headed households (Table 3).

As presented in Table 4, the average land allocated for maize crop by market participant households was 0.970 hectare while that of non-participants were 0.849 hectare. The result showed that land allocated for maize was statistically significant at $5 \%$. Thus, shows that the mean land of market participants was greater than that of nonmarket participants. This may indicates land allocated for maize could be seen as an incentive to produce surplus for market. The average annual maize production for market participants was $1512.800 \mathrm{~kg}$ while that of nonmarket participants was $673.333 \mathrm{~kg}$. Thus, high quantity of harvest could lead households to higher level of market participation.

A study result depicts that, the average extension contact by smallholder farmers was 7.567 for maize market participants and 11.782 for non-participants. This might be smallholder maize producers who have frequent contact with development agent could not get practical information on new technologies and agronomic practices which might boost their maize production. Instead development agents out of their profession, might spent their time with farmers talking about other issues which are not directly relevant to enhance farmers' production and productivity. In the study area, the average amount of credit obtained by sample households during the 
survey period was 4466.182 Ethiopian Birr/year for maize market participants and 2252.150 Ethiopian Birr/year for non-participants. This shows that farm households who obtained high amount of credit participated in maize market more than non-participants. The survey result in Table 4 depicts that average distance to the nearest market for the maize market participants was 63.472 while of non-participants was 74.495 walking minutes. Thus, there was statistically significant difference in distance to the nearest market across the maize market participants and non-participant households at $P<0.05$.

As presented in Table 4, 236 market participant households had good perception about lagged market price while 145 maize market participants had less perception about lagged market price. On other hand, about 73 of non-market participants had good perception about lagged market price while 92 non-market participants had less perception about lagged market price. The result shows significant difference between the groups in terms of perception about lagged market price at $1 \%$ significant level. Regarding cooperative membership, out of the total sample households 180 were member of the multipurpose cooperative and participated in maize market while 201 were non-members and participated in maize market. On the other hand, about 82 of non-market participants were member of cooperative and the remaining 83 non-participants were not members of cooperatives. Additionally, 249 market participant households got training while 132 market participants did not participate in training. On other hand, about 122 of non-market participants participated in training and the remaining 43 non-market participants did not participate in training. The result shows significant difference between the groups in terms of participation in training for maize market at $5 \%$.

\section{Econometrics analysis}

\section{Determinants of market participation decision} by smallholder maize producers

The analysis of factors affecting smallholder farmers' participation decision and its intensity in maize market was analyzed by using double-hurdle model regression. However, before running the final regression analysis all preliminary tests were made. Results for the determinants of maize market participation have a binary nature and estimated using the Probit model (the first-stage or tier one) as presented in Table 5. The likelihood ratio test indicates that, the overall goodness of fit of the doublehurdle model is statistically significant at $P<0.01$ significance level. This indicates that explanatory variables jointly explained the probability of participating in the maize market.
The double-hurdle model was fitted with 15 explanatory variables as presented in Table 5 . The first-stage model results show that nine variables-education level, farming experience, quantity of maize produced, cooperative membership, distance to nearest market, amount of credit received, off/non-farming income, number of oxen and perception about lagged price-significantly affect the market participation of smallholder maize producer farmers. While the second-stage result confirmed that seven variables-sex, family size, land allocated for maize, number of oxen owned, distance to nearest market, livestock holding and perception about lagged price-significantly affect the volume of supply to market by smallholder maize producer. The significant variables are described as follows.

Education level had negative and significant influences on the farmers' participation decision in maize market at $1 \%$ significance level. This indicates that attending education may create other job opportunities to participate in non-agricultural activities as employee. Marginal effect shows for each additional year of education, the farmers' participation decision in maize market decreases by $2.74 \%$, holding all other factors constant. This result is in line with [42] who found a negative and significant relationship between education level and maize producer market participation decision.

Farming experience is found to be significantly and negatively influencing market participation at $5 \%$ significance level. An increase in the farming experience of household head by 1 year decreases the probability of participating in the maize market by $0.42 \%$, all other factors held constant. This implies that older farmers (more experienced household heads) might be more concerned about being food secured and would not want to take the risk of demanding their crop banks. On contrary, younger household heads would engage in the markets probably they are more dynamic to adopt new technologies that enhance productivity. This result is consistent with the finding of [38] who found that that farming experience has negative effect in market participation decision.

Numbers of oxen owned have significant and positive effect on the probability of household participation in maize market at $5 \%$ level of significance. Ox is a production asset used in the study area. This implies that on average the probability of farmers' decision to participate in maize market increased by $4.04 \%$ as one additional ox to the maize producers. Thus, farmers owning higher number of ox can produce more maize output which increases marketable surplus. This finding is in agreement with finding of [64] who found that ownership of oxen increases output market participation due to its effect on production. Evidence from the study area reflected that farmers who had more number of oxen 
Table 5 Estimates of double-hurdle model for determinants of market participation. Source: own computation from survey result, 2018/19

\begin{tabular}{|c|c|c|c|c|c|c|}
\hline \multirow[t]{2}{*}{ Description of variables } & \multicolumn{3}{|c|}{ First-stage (Tier 1 ) } & \multicolumn{3}{|c|}{ Second-stage (Tier 2) } \\
\hline & Coef & Std. err. & Marginal effect & Coef. & Std. err. & $P>Z$ \\
\hline Sex of the household head & -0.204 & 0.170 & -0.0560 & $0.198^{*}$ & 0.119 & 0.095 \\
\hline Education level & $-0.116^{* * *}$ & 0.028 & -0.0274 & 0.013 & 0.019 & 0.502 \\
\hline Farming experience & $-0.016^{* *}$ & 0.007 & -0.0042 & -0.001 & 0.005 & 0.815 \\
\hline Cooperative Membership & $0.277^{*}$ & 0.153 & 0.0600 & -0.117 & 0.106 & 0.272 \\
\hline Family size & -0.008 & 0.028 & -0.0070 & $-0.036^{*}$ & 0.021 & 0.092 \\
\hline Land allocated for maize & 0.094 & 0.132 & 0.0038 & $0.789 * * *$ & 0.085 & 0.000 \\
\hline Number of oxen owned & $0.149^{* *}$ & 0.074 & 0.0404 & $0.181^{* * *}$ & 0.052 & 0.001 \\
\hline Distance to the nearest market & $-0.043^{* *}$ & 0.022 & -0.0136 & $-0.040^{* *}$ & 0.016 & 0.015 \\
\hline Credit amount received (log) & $0.033^{*}$ & 0.019 & 0.0116 & 0.019 & 0.013 & 0.154 \\
\hline Off/non-farm income (log) & $-0.069^{* * *}$ & 0.020 & -0.0234 & -0.021 & 0.015 & 0.168 \\
\hline Access to training & 0.220 & 0.141 & 0.0614 & -0.068 & 0.099 & 0.490 \\
\hline Livestock ownership (TLU) & 0.002 & 0.041 & -0.0067 & $-0.183^{* * *}$ & 0.030 & 0.000 \\
\hline Perception on lagged price & $0.068^{* * *}$ & 0.019 & 0.0240 & $0.058^{* * *}$ & 0.015 & 0.000 \\
\hline Maize quantity produced (log) & $0.617^{* * *}$ & 0.093 & 0.1595 & & & \\
\hline Distance to nearest road & & & & -0.021 & 0.027 & 0.428 \\
\hline _cons & $-3.703^{* * *}$ & 0.697 & & $5.537^{* * *}$ & 0.303 & 0.000 \\
\hline Sigma & & & & $0.896^{* * *}$ & 0.032 & 0.000 \\
\hline Wald/LR chi-square & 127.630 & & & 178.750 & & \\
\hline Number of observations & 546 & & & & & \\
\hline Wald $\operatorname{Chi}^{2}(14)=$ & 97.520 & & & & & \\
\hline Prob $>\mathrm{Chi}^{2}$ & 0.000 & & & & & \\
\hline Log likelihood (double-hurdle) & -769.546 & & & & & \\
\hline
\end{tabular}

"**", "**" and "***" represent statistical significance of factors at 10, 5 and $1 \%$ levels, respectively

were wealthier and had sufficient number of oxen to plough their field timely as a result of which they quickly decided to participate in the agricultural production activity. Oxen ownership was very important for farm operations. The same results were reported by $[38,65]$. This implies that oxen ownership has an influence on the participation decision in marketing in different areas.

Distance to nearest market has negative effect on maize market participation and found to be statistically significant at $10 \%$ significance level. The negative relationship indicates that the further is a household from the maize market, the more difficult and costly it would be to get involved in the maize market. The nearer a farmer is to the market, the easier to take the products to the market since the farmer may not incur a high cost for transportation. The marginal effect also confirms that an increase in walking minutes to the nearest market by one minute in maize market from the farm owner reduces the probability of participation decision in maize market by $1.36 \%$. This result is in agreement with the work of [63] and [66] who found the negative relationship between distance to market and the probability of participation in milk market. A study done by [19] also revealed that the longer the distance to the nearest market, the lower the participation of smallholder farmers in the marketing of their produce.

Credit amount received (log) has positively and significantly affected market participation decision of maize farmers at $10 \%$ significance level. The results of the study revealed that as the households obtained 1\% of the amount of credit the probability of maize market participation will increase by $1.16 \%$, all other factors held constant. This suggests that an increase in amount of credit improves the financial capacity of farmers to buy improved inputs, thereby increasing production which is reflected in the market supply of maize. This finding is in line with [57] who found that credit access had positive and significance influence on farmers' decision to participate in grain marketing. [14] also showed that positive and significant relationship between amount of credit and market participation decision.

As hypothesized, off/non-farm income $(\log )$ of the household heads had negatively affected maize market participation decision at $1 \%$ significance level. The marginal effect of the variable confirms that on average, if a maize producer gets off/non-farming income 
increment by $1 \%$ causes $2.34 \%$ reduction in probability of participating in maize market. This may be explained by the fact that farmers who have better non-farm income will not tend to generate cash from the selling of agricultural commodities (maize) rather from their non-farm income and consumes all produced maize for their household members. The possible reason is that maize commercialization is risk-bearing agricultural activities as compared to non/ off-farm income-generating activities. Furthermore, engagement in non/off-farm activities easily generates income in a short period of time. This finding is in line with the finding of [42] who found that getting more non/off-farm income represents additional wealth which constrains households not to participate in cash crops.

As it was expected, perception on lagged market price affected the farmer's decision to participate in maize market positively and significantly at $1 \%$ significance level. This result indicates that, as the farm household perceives previous year price was good the decision to participate will increase the probability of farmers to participate in maize marketing by $2.4 \%$, all other factors held constant. In line with this, a study conducted by [67] found that lagged price had a positive and significant effect on tomato farmers' decision to participate in the tomato market.

Quantity of maize produced (log) positively and significantly affects the probability of participation at $1 \%$ significant level. The positive and significant relationship between the variables indicates that as the amount of maize output produced increases, the probability of maize market participation also increases. The marginal effect of the variable also confirms that a $1 \%$ increase in amount of maize produced leads to the rise of the probability of maize household participation by $15.95 \%$. This can be explained by the fact that the higher the produce, the higher the farmers' motivation to participate more to generate additional income. This may also suggest that building the capacity of households to produce surplus production could be critical in improving households' participation in the market. This finding tallies with that of [21] who found that in Ethiopia when farmers produce more red bean, it motivates them to sell more. The higher the output, the higher is the farmer willing to participate in the market. [58] study found that in Ethiopia an increase in the number of livestock increased livestock farmers' market participation decision [55]. also found that when farmers produce more pepper, they are more likely to participate in the output market.

\section{Factors influencing intensity of maize market participation} The estimates factors affecting intensity of market participation second-stage of double-hurdle (log truncated) model was employed. Thus, the second hurdle result confirmed that seven variables-sex, family size, land allocated for maize, number of oxen owned, distance to nearest market, livestock holding and perception about lagged price-significantly affect the level market participation by smallholder maize producer.

The model result shows that, sex of the household significantly and positively influenced maize market participation level less than $10 \%$. Keeping other factors constant, as compared to the female-headed household male-headed household levels of maize market participation increase by $19.8 \%$. Because female-headed households are busy in doing of additional tasks like child caring, cooking in addition to farm activities. Besides, male-headed households have strong bargaining power in the marketing of the product and easy access of resources than their counter side. The result is consistent with the findings of $[5,22,28,41]$. They argued that males are more accessible to land and can cultivate large plots of land as compared to their female counterparts.

As presented in Table 5, family size affected the level of market participation negatively and significantly at less than 10\% level of significance. This entails that keeping other factors constant, an increase in family size by one result in a decrease in the level of maize market participation by $3.6 \%$. This indicates the volume of maize marketed would be determined by the number of family in the household. The higher the number of families, the higher amount of quantity would be required for consumption. That is, households with large family sizes need to feed their family first and take the remaining small portion surplus to the market Then this results in a lower amount of maize quantity would be marketed and it brings a low level of market participation. The result is consistent with the finding of $[28,40,49,54,68]$.

Land allocated for maize production had a positive and significant contribution to the level of maize market participation at less than $1 \%$ level of significance (Table 5). An increase in landholding by one hectare results an increase in the level of participation in the maize market by $78.9 \%$ of maize. This is due to the reason that owning of the large area of land enables them to produces for market purposes and supply more mount of maize product to the market. This result was in confirmatory with the finding of $[28,51,52]$ found that land allocated for output production positively affected marketable surplus of outputs.

Oxen ownership was found to have a positive and significant influence on the level of participation in maize market at less than $1 \%$ level of significance. An increase 
in the number of oxen ownership by one unit results in an increase in maize market participation level by $18.1 \%$. Since oxen are used as traction power which enables farm households to produces in large quantity and enhances the market participation level. This result was in line with the finding of $[13,49-51]$, confirming that the number of oxen influences market participation level positively.

As hypostasized, the distance to the nearest market had negatively and significantly affected the intensity of maize market participation at a $5 \%$ significance level. The result showed that an increase in walking minutes to the nearest market by one minute, the level of participation in maize market decreased by $4 \%$. Since maize is one of the agricultural products which was difficult to carry and travel long distance for long hour. The result is in line with the findings of $[40,50]$ that state as the longer the distance of the market it is more costly and time-consuming to travel holding more output especially if there is no transportation facility.

The number of livestock owned by households is negatively and significantly affects the intensity of market participation at less than $1 \%$ level significance. The model result revealed that an increase in the number of livestock by one tropical livestock unit results in a decrease in market participation level by $18.3 \%$. It is known that livestock and crop production are competing enterprises for the available resources. This means that households who have large size livestock give more resources and more time in deployment. Hence, this in turn results decrease in the market participation level of farm households. This result was in line with the finding of $[50,54,68,69]$ found that large size of livestock ownership reduces the market participation level of the crop.

Finally, as indicated in Table 5, households' perception towards lagged year market price significantly and positively affected the level of maize market participation at less than $1 \%$. It was expected that farmers could have different perceptions regarding with maize market lagged year price. According to model results as compared to households who perceive low lagged year prices, households who perceived high lagged year price level of participation increases by $5.8 \%$. The finding is in line with the finding of $[28,40,62,70]$ who state that high perception of lagged year enabled level of market participation.

\section{Conclusions}

Considering the smallholder farmers' market participation is a critical issue in improving household welfare in rural areas and poverty reduction in developing countries like Ethiopia. However, given the area coverage and high production of major food cereal crops such as maize by smallholder farmers, they face several constraints that make it difficult for them to participate in the agricultural markets. The study result generated good information through employing double-hurdle model approaches on constraints hindered the smallholder farmers' participation decision on maize market. Results of cross-sectional survey indicates that, out of total 546 maize producers, 381 households are maize market participants and 165 households are non-participants in 2018/2019 production year. The double-hurdle model approaches findings suggest that education level, farming experience, quantity of maize produced, cooperative membership, distance to nearest market, amount of credit received, off/non-farm income, number of oxen owned and perception about lagged price significantly affect the market participation decision of smallholder maize producer farmers. While, sex of household head, family size, land allocated for maize, number of oxen owned, distance to nearest market, livestock holding and perception about lagged price significantly affect the level market participation by smallholder maize producers. The findings of this research indicated that higher levels of crop production enhanced smallholders' market participation, implying that strategies that aim at improving household capacity to produce surplus production through optimal allocation of resources like land, oxen and enhancing productivity, could have high returns in promoting smallholders' commercial transformation. Government sectors should work together on strengthening, time allocation for non-farm activities, and family planning programs through control policies on improving rural family planning to enhance farmers' livelihood and market participation and become commercial oriented producers. Based on the findings of this study, it is recommended that strengthening supportive institutions such as credit access would create financial capacity of farm households to purchase agricultural inputs and other expenses; thereby increase market supply and improve their market participation decision. In addition, findings indicate that promotion of better access to infrastructure like market networks, price information, road and transport facilities and other institutional services to promoting market participation among smallholder farmers. Therefore, understanding these socio-economic factors is very important for policy-making to address the problem of market participation decision and its intensity among small holder farm households.

\footnotetext{
Abbreviations

CSA: Central Statistical Agency; ETB: Ethiopian Birr; HH: Household head; IFPRI: International Food Policy Research Institute; kg: Kilogram; NGOs: Non-governmental organizations; MoARD: Ministry of Agriculture and Rural Development; PPS: Probability proportion to size; SNNPRS: South Nations Nationalities and Peoples Region State.
} 


\section{Acknowledgements}

We would like to express our sincere gratitude to Mizan Tepi University for providing financial support to conduct this research work. We wish to convey our heartfelt thanks to number of individuals and organizations who have contributed to this work. We would also like to extend our profound appreciation to all the sample households, the enumerators for their patience throughout the data collection process and provide all the necessary and relevant information, without which this document could have not been written.

\section{Authors' contributions}

$\mathrm{KH}, \mathrm{EG}$ and $\mathrm{AW}$ equally contributed to conceptualization; methodology; software; formal analysis; investigation; resources; data curation; writing-original draft preparation; writing - review and editing; visualization; supervision; project administration; funding acquisition. All authors read and approved the final manuscript.

\section{Funding}

The authors would like to thank Mizan Tepi University for providing financial support for data collection and writing of this study.

\section{Availability of data and materials}

The data used to support the findings of this study are available from corresponding author upon request.

\section{Declarations}

\section{Ethics approval and consent to participate}

Not applicable.

\section{Consent for publication}

Not applicable.

\section{Competing interests}

The authors declare that they have no competing interests.

\section{Author details}

'Department of Agricultural Economics, Mizan-Tepi University, P.O Box: 260, Mizan Aman, Ethiopia. ${ }^{2}$ Department of Agricultural Economics, Mizan-Tepi University, P.O Box: 260, Mizan Aman, Ethiopia.

Received: 7 January 2021 Accepted: 10 January 2022

Published online: 03 March 2022

\section{References}

1. Gebre-Selassie A, Bekele T. A review of Ethiopian agriculture: roles, policy and small-scale farming systems. In: Eder C, Kyd-Rebenburg D, Prammer J, editors. Global growing casebook-insights into African agriculture (Global Growing Campaign). 2012. p. 36-65. http://global-growing.org/

2. MoARD. Ethiopia's agricultural and sector policy and investment framework (PIF): 2010-2020, Addis Ababa, Ethiopia. 2010.

3. Dorosh P, Thurlow J, Kebede FW, Ferede T, Taffesse AS. Structural change and poverty reduction in Ethiopia: economy wide analysis of the evolving role of agriculture. vol. 123. Washington, D.C.: International Food Policy Research Institute. 2018.

4. Gebremedhin B. Commercialization of smallholders: does market orientation translate into market participation? vol. 22. ILRI (aka ILCA and ILRAD). 2010.

5. Olwande J, Smale M, Mathenge MK, Place F, Mithöfer D. Agricultural marketing by smallholders in Kenya: a comparison of maize, kale and dairy. Food Policy. 2015;52:22-32. https://doi.org/10.1016/j.foodpol.2015.02.002.

6. Mitku A. Impact of smallholder farmers'agricultural commercialization on rural households' poverty. Int J Appl Econ Finance. 2014;8:51-61.

7. CSA. Central Statistical Agency key findings of the $2017 / 2018$ G.C agricultural sample surveys, Addis Ababa, 2018. http://www.statsethiopia.gov.et

8. IFPRI. International Food Policy Research Institute report of 2010 https:// www.ifpri.org/publication/2010-annual-report.

9. CSA. Central Statistical Agency Agricultural sample survey 2016/2017 G.C, report on area and production of major crops, agricultural sample survey. volume I, Statistical Bulletin 584, 2017, Addis Ababa, Ethiopia. https:// www.statsethiopia.gov.et.

10. Heltberg R, Tarp F. Agricultural supply response and poverty in Mozambique. In: Presented paper at the conference on growth and poverty at WIDER. 25-26 May 2001, Institute of Economics, University of Copenhagen.

11. Hagos A, Geta E. Review on smallholders' agriculture commercialization in Ethiopia: what are the driving factors to focused on? J Dev Agric Econ. 2016;8(4):65-76.

12. Bedaso T, Wondwosen T, Mesfin K. Commercialization of Ethiopian smallholder farmer's production: Factors and Challenges behind. In: Paper presented on the tenth international conference on the Ethiopian economy, Ethiopian Economics Association, July 19-21, 2012, Addis Ababa, Ethiopia. 2012.

13. Berhanu G, Moti J. Commercialization of smallholders: is market participation enough? AAAE third conference/AEASA 48th conference, September 19-23, 2010, Cape Town, South Africa. No. 96159.African Association of Agricultural Economists (AAAE) and Agricultural Economics Association of South Africa (AEASA). 2010

14. Mabiratu D, Prem KD, Gersam D. Determinants of maize commercialization among smallholder farmers: the case of Nunu Kumba District, East Wollega Zone, Oromia Regional State, Western Ethiopia. Asian J Agric Ext Econ Sociol. 2019;37(4):1-8.

15. Mahelet $\mathrm{G}$. Factors affecting commercialization of smallholder farmers in Ethiopia: the case of North Omo Zone, SNNP region. In: Paper presented at the 5th international conference on the Ethiopian economy, 7-10 June 2007, Addis Ababa, Ethiopia (2007).

16. NPC (National Planning Commission). Federal Democratic Republic of Ethiopia Growth and Transformation Plan II (GTP II) (2015/16-2019/20). Volume I: NPC May, 2016, Addis Ababa.

17. Workneh $N$, Michael R. Intensification and crop commercialization in north eastern Ethiopia. Ethiop J Econ. 2002:11(2):83-105.

18. Bekele A, Belay K, Legesse B, Lemma T. Effects of crop commercial orientation on the productivity of smallholder farmers in drought-prone areas of the Central Rift Valley of Ethiopia. J Rural Dev Nongchon-Gyeongju. 2010;33(1071-2016-86943):105-28.

19. Gebremedhin B, Jaleta M, Hoekstra D. Smallholders, institutional services, and commercial transformation in Ethiopia. Agric Econ. 2009;40(s1):77387. https://doi.org/10.1111/j.15740862.2009.00414.x

20. Pender J, Place F, Ehui S, editors. Strategies for sustainable land management in the East African highlands. Washington, DC: International Food Policy Research Institute (IFPRI); 2006.

21. Agete J. Analysis of factors influencing participation of smallholder farmers in Red Bean Marketing in Halaba Special District, Ethiopia. MSc Thesis, University of Nairobi, Nairobi, Kenya. 2014.

22. Tufa A, Bekele A, Zemedu L. Determinants of smallholder commercialization of horticultural crops in Gemechis District, West Hararghe Zone. Ethiop Afr J Agric Res. 2014;9(3):310-9.

23. Regasa Megerssa G, Negash R, Bekele AE, Nemera DB. Smallholder market participation and its associated factors: evidence from Ethiopian vegetable producers. Cogent Food Agric. 2020;6:1. https://doi.org/10 1080/23311932.2020.1783173.

24. Hailu G, Manjur K, Meles K. Crop commercialization and smallholder farmers livelihood in Tigray region, Ethiopia. J Dev Agric Econ. 2015;7(03FBD3954989):314-22. https://doi.org/10.5897/JDAE2015.0649.

25. Demeke L, Haji J. Econometric analysis of factors affecting market participation of smallholder farming in Central Ethiopia. J Agric Econ Ext Rural Dev. 2014;2(6):094-104

26. Omiti JM, Otieno DJ, Nyanamba TO, McCullough E. Factors influencing the intensity of market participation by smallholder farmers: a case study of rural and peri-urban areas of Kenya. Afr J Agric Resour Econ. 2009;3:71.

27. Rabbi F, Ahamad R, Ali S, Chandio AA, Ahmad W, Ilyas A, Din IU. Determinants of commercialization and its impact on the welfare of smallholder rice farmers by using Heckman's two-stage approach. J Saudi Soc Agric Sci. 2017;18(2):224-33. https://doi.org/10.1016/j.jssas.2017.06.001.

28. Mazengia Y. Smallholders' commercialization of maize production in Guangua district, northwestern Ethiopia. World Sci News. 2016:58:65-83.

29. KZAO. Kaffa Zone Administrative Office Geographical Location Profile Data of the Kaffa Zone. 2018

30. CSA (Central Statistical Agency). Population projection of Ethiopia for all regions at woreda level from 2014-2017. Addis Ababa :Federal Democratic Republic of Ethiopia. 2013. https://www.statsethiopia.gov.et. 
31. Mohammed W. Prevalence and distribution survey of an invasive alien weed (Parthenium hysterophorus L.) in Sheka zone, Southwestern Ethiopia. Afr J Agric Res. 2010;5(9):922-7. https://doi.org/10.5897/AJAR09.048.

32. CSA. Central Statistical Agency Agricultural sample survey report on area and production of major crops (Meher season). Statistical Bulletin, vol. I, Addis Ababa, Ethiopia, 2018. http://www.statsethiopia.gov.et.

33. Bingxin $Y$, José $F$, Sinafikeh A. Cereal production and technology adoption in Ethiopia. Development Strategy and Governance Division. Int. Food Policy Res. Inst.; 2011.

34. Cragg JG. Some statistical models for limited dependent variables with application to the demand for durable goods. Econometrica. 1971;39:829-44.

35. Heckman JJ. Sample selection bias as a specification error. Econometrica. 1979: 47:153-61.

36. Wooldridge JM. Econometric analysis of cross section and panel data, 2nd ed. 2010.

37. Christoph E, Peter GM. dhreg, xtdhreg, and bootdhreg: Commands to implement double-hurdle regression. Stata J. 2014;14(4):778-97.

38. Edosa TL. Determinants of commercialization of teff crop in Abay Chomen District, Horo Guduru wallaga zone, Oromia Regional State, Ethiopia. J Agric Ext Rural Dev. 2018;10(12):251-9. https://doi.org/10.5897/JAERD2018.0970.

39. Belayneh NG, Tegegne B, Ademe A. Determinants of smallholder teff producer farmers market participation in Merhabete District, Amhara Region, Ethiopia. Int J Agric Econ. 2019;4(4):135-43. https://doi.org/10.11648/j.ijae. 20190404.11.

40. Benjamin A, Yaw O, Seini W. Market participation of smallholder maize farmers in in the upper West region of Ghana. Afr J Agric Res. 2014;9(31):2427-35.

41. Sigei $G$, Bett $H$, Kibet L. Determinants of market participation among smallscale pineapple farmers in Kericho County, Kenya, Egerton. 2014.

42. Gelana OM, Aweke CS, Okoyo EN. Determinants of farmers' participation and intensity of participation in groundnut commercialization: evidence from Babile District, Oromia national Regional State, Ethiopia. Int J Adv Res. 2020;8(03):1065-74.

43. Mazengia Y. Smallholders commercialization of maize production in Guangua District, Northwestern Ethiopia. World Sci News. 2016:58:65-83.

44. Tariku Ayele D, Tegegne B, Zemedu L. Analysis of market decisions and intensity of market participation of smallholder wheat farmers in Adola Rede District of Oromia Regional State, Ethiopia. Int J Res Stud Agric Sci. 2018;4(8):1-11. https://doi.org/10.20431/2454-6224.0408001.

45. Alene AD, Manyong VM, Omanya G, Mignouma HD, Bokanga M, Odhiambo G. Smallholder market participation under transactions costs: maize supply and fertilizer demand in Kenya. J Food Policy. 2008;3(3):318-28.

46. Gani BS, Adeoti Al. Analysis of market participation and rural poverty among farmers in northern part of Taraba State, Nigeria. J Econ. 2011;2(1):23-36.

47. Amha W. Food grain marketing in Ethiopia after the market reform 1990. A case study in Alaba Siraro District. Berlin: Verlag Koster; 1994.

48. Somano W. Dairy marketing chains analysis: the case of Shashemane, Hawassa and Dale district's milk shed, southern Ethiopia. MSc thesis. Haramaya University; 2008.

49. Beadgie WY, Reddy P. Determinants of market participation and intensity of marketed surplus among maize producers in Fogera District of South Gondar Zone. Addis Ababa: Heckman Two Stage Equation Approach; 2020.

50. Leta ET. Determinants of commercialization of Teff crop in Abay Chomen district, Horo Guduru Wallaga zone, Oromia regional state, Ethiopia. J Agric Ext Rural Dev. 2018;10(12):251-9.

51. Shewaye A, Dawit A, Lemma Z. Determinants of haricot bean market participation in Misrak Badawacho District, Hadiya zone, Southern Nations Nationalities and Peoples Regional State, Ethiopia. Ethiop J Agric Sci. 2016;26(2):69-81.

52. Alemu G. Analyzed market performance and determinants of marketed surplus of Teff: the case of Bacho Woreda in South West Shewa Zone, Oromia national regional state. M.Sc. Thesis. Haramaya University. 2015.

53. Toma T, Tegegn B, Zemedu L. Determinants of honey market supply: the case of Shebedino District, Sidama Zone, SNNPR, Ethiopia. J Econ Sustain Dev. 2017:8(19):7-10.

54. Tura EG, Goshub D, Demise T, Kenead T. Determinants of market participation and intensity of marketed surplus of teff producers in Bacho and Dawo Districts of Oromia State, Ethiopia. J Econ Sustain Dev. 2016;7(1):13-24.

55. Mussema R, Dawit A. Red pepper marketing in Siltie and Alaba in SNNPRS of Ethiopia: factors affecting households' marketed pepper. Int Res J Agric Sci Soil Sci. 2012:2(6):261-6.
56. Abafita J, Atkinson J, Kim C-S. Smallholder commercialization in Ethiopia: market orientation and participation. Int Food Res J. 2016;23(4):1797-807.

57. Ashenafi A. Analysis of grain marketing in Southern Zone of Tigray Region, Ethiopia, MA. Thesis, Mekelle University, Ethiopia. 2010.

58. Holloway G, Nicholson C, Delgado C, Staal S, Ehui, E. How to make milk market: a case study from Ethiopian high lands. Socio-economic and policy research working paper 28. Nairobi: ILRl; 2000. p. 85.

59. Ademe A, Legesse B, Haji J, Goshu D. Smallholder farmers' crop commercialization in the highlands of eastern Ethiopia. Rev Agric Appl Econ. 2017;20(2):30-7.

60. Lijalem BBT. Farmers market participation decision and intensity of participation in butter and cheese marketing: the case of Loma Woreda, Dawuro Zone Southern Ethiopia. J Market Consumer Res. 2019;54:13-23. https://doi. org/10.7176/JMCR.

61. Tadesse B, Shumeta Z, Tolemariam T. Determinants of dairy farmers' market participation in the major dairy producing towns of Jimma Zone of Southwest Ethiopia. Food Sci Qual Manag. 2016;52:66-75.

62. Musah AB, Osei-Asare YB, Wayo S. Market participation of smallholder maize farmers in the Upper West Region of Ghana. Afr J Agric Res. 2014;9(31):2427-35. https://doi.org/10.5897/AJAR2014.8545.

63. Gizachew G. Dairy Marketing patterns and efficiency: the case of Ada' Liben District, eastern Oromiya. M.Sc. Thesis presented to Alemaya University, Ethiopia 2005

64. Matz J. Smallholder Participation in the Commercialization of Vegetables: Evidence from Kenyan Panel Data, ZEF-Discussion Papers on Development Policy No. 185, Center for Development Research, Bonn, 2014.

65. Birara E, Mezegebu A, Fenta A, Zemen A. Determinants of wheat commercialization among smallholder farmers in Debre Elias Woreda, Ethiopia. Adv Agric. 2020;2020:12. https://doi.org/10.1155/2020/2195823.

66. Holloway G, Ehui S. Expanding market participation among smallholder livestock producers: a collection of studies employing Gibbs sampling and data from the Ethiopian highlands, 1998-2001. Socio-economic and policy research working paper no. 48. Nairobi: International Livestock Research Institute; 2002. P. 1-88.

67. Abay A. Vegetable market chain analysis in Amhara National Regional State: the case of Fogera Woreda, South Gondar Zone. MSc thesis. Haramaya: Haramaya University; 2007. https://hdl.handle.net/10568/623. Accessed 15 July 2018.

68. Aliyi I, Tadesse B, Demise T. Determinants of intensity of market participation of smallholder rice producers: the case of Shebe Sombo District, Southwest Ethiopia. J Agric Econ Dev. 2018;7(3):013-22.

69. Mebrahatom M. Determinants of commercialization of teff and its factor productivity outcome, the case of Tahtay Qoraro woreda, Northwest Zone of Tigray Regional State, Ethiopia. Thesis submitted to School of Graduate Study of Haramaya University. 2014.

70. Mihretie YA. Smallholder wheat farmers' commercialization level and its determinants in northwestern Ethiopia. Afr J Sci Technol Innov Dev. 2020. https://doi.org/10.1080/20421338.2020.1773202.

\section{Publisher's Note}

Springer Nature remains neutral with regard to jurisdictional claims in published maps and institutional affiliations.

Ready to submit your research? Choose BMC and benefit from:

- fast, convenient online submission

- thorough peer review by experienced researchers in your field

- rapid publication on acceptance

- support for research data, including large and complex data types

- gold Open Access which fosters wider collaboration and increased citations

- maximum visibility for your research: over 100M website views per year

At BMC, research is always in progress.

Learn more biomedcentral.com/submissions 